\title{
Tidal effects on short-term mesozooplankton distribution in small channels of a temperate-turbid estuary, Southwestern Atlantic
}

\author{
Javier Chazarreta*, Monica Susana Hoffmeyer, Diana G. Cuadrado, Anabela Anahí Berasategui
}

Instituto Argentino de Oceanografía (IADO-CONICET-BB)

(Po Box 804- 8000 Bahía Blanca, Argentina. Ph/Fax: 54-291-4861112)

*Corresponding author: javierchaza@gmail.com

\begin{abstract}
The short-term variability of mesozooplankton distribution and physicochemical variables was examined in two different channels of the Bahía Blanca Estuary, Argentina, during two tidal cycles. All the physicochemical measurements and mesozooplankton sampling were performed at a fixed site during approximately $22-23 \mathrm{~h}$ at 3-h intervals. Pumps were used to obtain surface and bottom mesozooplankton samples and the water speed of each stratum was measured with an Acoustic Doppler Current Profiler (ADCP). In all, 23 mesozooplanktonic taxa belonging to four phyla (Arthropoda, Annelida, Echinodermata and Chordata) were identified. The most abundant taxa during the two tidal cycles were Balanus glandula larvae, Eurytemora americana and Acartia tonsa. A discernible variability in the water conditions and vertical mesozooplankton distribution (VMD) different from that known for the estuary's main channel, was found in the other two selected channels. VMD varied during the tidal cycle in both channels in accordance with the channel's geomorphology and water dynamic characteristics of each of them. The variation of the abundance of the different taxa during ebb and flood currents might indicate the existence of a tidal vertical migration of the mesozooplankton as a response to particular dynamic water conditions.
\end{abstract}

Descriptors: Zooplankton, Estuary, Tidal Currents, Vertical Distribution, ADCP, Tidal Vertical Migration.

\section{RESUMo}

A variação de curto prazo da distribuição do mesozooplâncton e das variáveis físico-químicas foi examinada em dois diferentes canais do Estuário de Bahia Blanca, Argentina, durante dois ciclos de maré. As medidas físico-químicas e a amostragem do zooplâncton foram realizadas em dois locais fixos durante aproximadamente 22-23 horas, com intervalos de 3 horas. Bombas foram utilizadas para obter amostras de zooplâncton na superfície e no fundo e a velocidade da água em cada estrato foi medida com o Perfilador Acústico de Corrente (ADCP). Ao todo, foram identificados 23 taxa mesozooplanctônicos pertencentes a 4 filos (Arthropoda, Annelida, Echinodermata e Chordata). Os grupos mais abundantes durante os dois ciclos de maré foram larvas de Balanus glandula, além de Eurytemora americana e Acartia tonsa. Nos dois canais selecionados foi identificada uma variação nas condições da água e na distribuição vertical do mesozooplâncton (DVZ) diferente daquela conhecida para o canal principal do estuário. DVZ variou durante o ciclo de maré em ambos os canais de acordo com a geomorfologia e características da dinâmica das águas existente em cada um deles. A variação na abundância dos diferentes taxa durante as marés vazante e enchente poderia estar indicando a existência de migração vertical do mesozooplâncton em resposta a uma determinada condição dinâmica da água.

Descritores: Zooplâncton, Estuário, Correntes de maré, Distribuição vertical, ADCP, Migração vertical. 


\section{INTRODUCTION}

Estuaries are among the most productive ecological systems around the world (WILSON, 2002) and in temperate zones they support major fisheries, aquaculture, tourism, recreational activities and intensive agriculture in their basins (LEANDRO et al., 2007). Deeper insight into the variability of these ecosystems at different temporal-spatial scales is therefore a prerequisite to understanding the composition and abundance dynamics of estuarine mesozooplankton. Tides, winds and estuarine circulation influence the composition and abundance of estuarine zooplankton, also affecting zooplankton assemblage composition and therefore their spatial (vertical and horizontal) distribution (HILL, 1991; WIAFE; FRID, 1996; DAUVIN et al., 1998; KIMMERER et al., 1998, 2002; PEITSCH et al., 2000; ROMAN et al., 2001; MOUNY; DAUVIN, 2002; NAYLOR, 2006; THORISSON，2006; DEVREKER et al., 2008, 2010; HSIEH et al., 2010; UEDA et al., 2010; SCHMITT et al., 2011; MENENDEZ et al., 2011, 2012; GONÇALVES et al., 2012; DA COSTA et al., 2013). The temporal variation in environmental conditions is another main factor strongly affecting the occurrence, features and distribution of zooplankton assemblages (DAUVIN et al., 1998; MARQUES et al., 2009; DUTTO et al., 2012). The vertical distribution of plankton is particularly affected by the speed and direction of currents (HILL, 1991). Selective tidal stream transport may also be responsible for retention or export of organisms from the estuarine environment through differential behavioral mechanisms (MORGAN et al., 1997; JAGGER, 1999; GARRISON, 1999; PEREIRA et al., 2000; MENENDEZ et al., 2012).

The influence of tides on zooplankton is a well-known phenomenon in different types of coastal-estuarine environments, though attention has been focused mainly on assessing these effects in large coastal channels with direct connection to the open shelf or to main navigation channels in estuaries (HOUGH; NAYLOR, 1991; MORGAN et al., 1997; VILLATE, 1997; DAUVIN et al., 1998; KRUME; LIANG, 2004; MORGADO et al., 2006; SCHWAMBORN et al., 2008; HSIEH et al., 2010). Several such studies have addressed the relationships between tidal wave and mesozooplankton characteristics in the main channel of the Bahía Blanca estuary (BBE) along the inner and intermediate zones (MENENDEZ et al., 2011, 2012). These authors concluded that mesozooplankton distribution is strongly influenced by tides on short-time scales. The abundance of Acartia ton$s a$, the dominant copepod in this estuary particularly during summer, is strongly affected by the rhythm of the tides (MENENDEZ et al., 2011, 2012). These findings were corroborated by MENENDEZ et al. (2012), who found higher abundances of this species at the margins and near the bottom of the main channel during ebb tide. This fact provides evidence for the existence of some mechanism that allows organisms to avoid strong currents during this tidal state. Copepod species such as Acartia tonsa, Paracalanus parvus, Labidocera fluviatilis and Euterpina acutifrons remain at the bottom most of the time where the currents are usually less powerful, thus enabling them to avoid being swept away by the ebb tide towards the estuarine mouth.

There is currently less information available on tidal effects on plankton in small estuary channels than in large channels and on the combined effects of tide and geomorphological features. We hypothesize that the pattern of zooplankton distribution over the tidal cycles differs from that in large channels such as this estuary's main channel. In this context, the aim of the present study was to examine short-term changes in mesozooplankton distribution, thus contributing to understand the role of these small channels in estuaries.

\section{MATERIAL AND METHODS}

Bahía Blanca Estuary (BBE) is located in a semi-arid temperate zone on southern Argentina's Atlantic coast $\left(38^{\circ} 45^{\prime}-39^{\circ} 40^{\prime} \mathrm{S} 61^{\circ} 45^{\prime}-62^{\circ} 30^{\prime} \mathrm{W}\right)$. It covers an area of $2300 \mathrm{~km}^{2}$ and is characterized by the development of a dense network of interconnected channels forming meanders at low tide. Extensive tidal flats and marshes define the areas adjacent to the channels. The water surface covers an area of approximately $1300 \mathrm{~km}^{2}$ at high tide, reduced to $400 \mathrm{~km}^{2}$ at low tide (CUADRADO et al., 2004). The BBE has a maximum depth of $25 \mathrm{~m}$ and a vertically homogeneous water column as a result of mixing due to the effect of tides and wind suspending fine sediments (PERILLO et al., 2001). The freshwater input is low and derives mainly from the Sauce Chico creek and the Napostá Grande stream, which provide an average annual flow of only 1.9 and $0.8 \mathrm{~m}$ s-1, respectively (PERILLO; PICCOLO, 1991). The water movement is driven by a semidiurnal tidal wave, the main energy input to the system, modified by geomorphology and winds. The mean amplitude of the tide varies between 3.5 $\mathrm{m}$ at the head, decreasing to $2.2 \mathrm{~m}$ at the mouth (PERILLO; PICCOLO, 1991; PERILLO et al., 2001). 
Canal Vieja (CV) and Bahía del Medio (BM), both located in the inner estuarine zone, were the two channels selected for the sampling and to test our hypothesis (Figure 1), CV is $300 \mathrm{~m}$ wide, has a mean depth of $6.5 \mathrm{~m}$ and is located at the north-western margin of estuary (TOMBESI et al., 2000). This channel connects directly to the main channel and lies parallel to the latter and to the north of it. It is strongly impacted by sewage pollution, continuously receiving the waste water discharge from Bahía Blanca city (TOMBESI et al., 2000; MARCOVECCHIO et al., 2008; BIANCALANA et al., 2012). In contrast, $B M$ is $70 \mathrm{~m}$ wide, has a mean depth of $4.5 \mathrm{~m}$ and is located southwestwards of the estuary's main channel. It is considered unpolluted (HOFFMEYER; BARRÍA, 2007), has no direct connection to the main channel and is part of a system of channels forming a loop completely surrounded by a large extension of marsh (GINSBERG; ALIOTTA, 2011). A number of studies carried out in recent years have provided considerable background information and data on environmental features such as temperature, salinity, $\mathrm{pH}$, oxygen, particulate organic matter and on the zooplankton characteristics of both channels (BALDINI et al., 1999; TOMBESI et al., 2000; HOFFMEYER; BARRIA, 2007; MARCOVECCHIO et al., 2008; BIANCALANA et al., 2012; DUTTO et al., 2012).

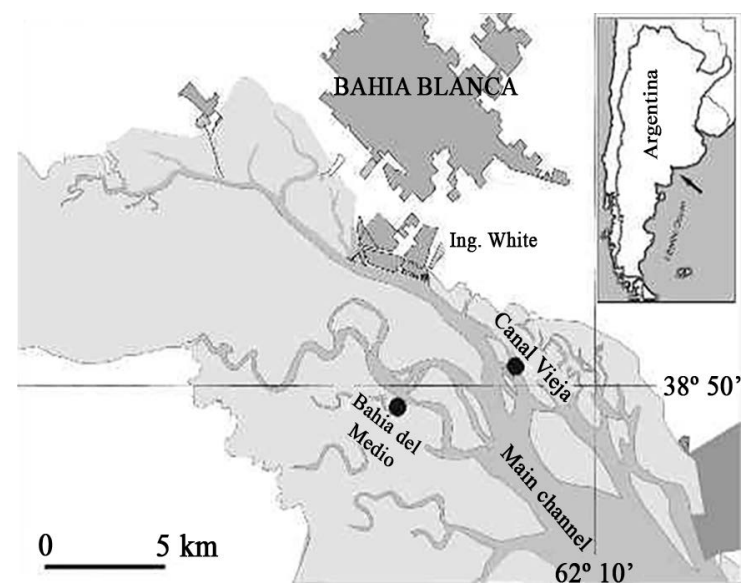

Figure 1. Map of the Bahía Blanca Estuary (BBE), Argentina, showing the location of the sampling stations.

Sampling was conducted aboard an oceanographic coastal boat in winter: on 07/15/2008 in CV and 07/22/2008 in BM. All the field tasks were performed at a fixed site over approximately 22-23 h (including almost two tidal cycles). All the physicochemical measurements and mesozooplankton sampling were carried out in synchrony with a $3 \mathrm{~h}$ frequency, starting at low tide $(\mathrm{N}=32)$. Sampling times were arranged according to the schedule set for the tides predicted by the Argentine Hydrographic Service and these coincided with the transition from spring to neap tides. Mesozooplankton samples were obtained from one meter below the surface and one meter above the bottom using two stainless steel submersible centrifugal Grundfos ${ }^{\circledR}$ pumps connected by a flexible hose to a manifold funnel and a $200 \mu \mathrm{m}$ plankton net located on the boat's deck. The pumped water was filtered through the net for 15 to 30 min until a total volume varying between 1.9 and $4.2 \mathrm{~m}^{3}$ was obtained. Samples were immediately fixed with $4 \%$ formalin and stored until they could be studied in the laboratory. Temperature, conductivity, salinity and $\mathrm{pH}$ were measured at each sampling time and depth using a Horiba ${ }^{\circledR}$ multisensor probe. The tidal current velocity across the water column was measured with an Acoustic Doppler Current Profiler (ADCP), supported by a bracket on the hull of the vessel and working in a quasistatic state. Mesozooplancton samplings were synchronized with the measurements of water current velocity and environmental variables covering the same time period each $3 \mathrm{~h}$, approximately at the middle of flood tide (F), high tide (HT), middle of ebb tide (E) and low tide (LT).

The qualitative analyses and the correct taxonomic identification of mesozooplankton organisms in the samples were performed in the laboratory using a Wild M5 ${ }^{\circledR}$ stereo microscope and a C ZEISS ${ }^{\circledR}$ Standard microscope in order to achieve the lowest possible level of taxonomic classification (HOFFMEYER, 1983; BOLTOVSKOY, 1999; YOUNG, 2002; HOFFMEYER, 2004; HOFFMEYER; CERVELLINI, 2004; HOFFMEYER; MIANZAN, 2004). Quantitative analysis was carried out by a total count of the organisms in the samples using a Bogorov type chamber under a Wild M5 stereo microscope. Both analyses were performed on formaline-free samples. Zooplankton abundance is expressed as the number of individuals per cubic meter.

Data of the measured or estimated environmental and biotic variables were compared to find statistically significant differences between sites and depths. Due to the lack of data normality and homoscedasticity, the non-parametric Mann-Whitney U test (ZAR, 1999) was used for these comparisons. Only taxa with a relative abundance greater than $1 \%$ of the total organisms' contribution to each collected sample were included in the analyses, which were performed with a significance level of 0.05 using 
$\mathrm{NCSS}^{\circledR} 2007$ software. Diversity of taxa was estimated by calculating the Shannon-Wiener index $\left(\mathrm{H}^{\prime}\right)$ in terms of $\log 10$ (SHANNON; WEAVER, 1949), evenness with the Pielou index (J') (PIELOU, 1975) and dominance using the Simpson index $\left(\lambda^{\prime}\right)$ (SIMPSON, 1949). In addition, taxa richness $(\mathrm{S})$ was assumed to be equal to the number of taxa encountered in each sample. Comparisons of these parameters among depths and sites were also performed using the Mann-Whitney U test.

\section{RESULTS}

The relationship between the physicochemical variables temperature, salinity, $\mathrm{pH}$ and water velocity obtained during the period of measurement in the water column at both sites are shown in Figure 2. The highest surface and bottom current velocities were obtained during the ebb tide at both sites. The remaining variables were almost constant during the two tidal cycles, though the temperature increased in CV during the ebb tide both at the surface and bottom, with values ranging between 10.1 and $13.2{ }^{\circ} \mathrm{C}$ and 9.7 and $12.6^{\circ} \mathrm{C}$, respectively. This increase in temperature coincided with a slight decrease in salinity. The environmental variables showed no significant differences between depths - with the exception of salinity, which was significantly higher at the bottom than at the surface in both channels $(p=0.019 \mathrm{CV}$ and $p$ $=0.029 \mathrm{BM}$ ). Highly significant differences were observed between sites in terms of temperature, salinity and $\mathrm{pH}$, but not of water velocity. Temperature and $\mathrm{pH}$ were higher in $\mathrm{CV}$ than $\mathrm{BM}$, whereas salinity was higher in BM.

In all, 23 mesozooplanktonic taxa belonging to four phyla (Arthropoda, Annelida, Echinodermata, and Chordata) were identified during this study (Table 1). Adventitious plankton were the best represented group followed by holoplanktonic Copepoda taxa and finally meroplanktonic larvae. The taxa richness (S) of these latter groups was 10, 8 and 5, respectively. The average total mesozooplankton abundance over the period of this study was $133.80 \pm 19.28$ ind. $\mathrm{m}^{-3}$. The mean abundance values of the main taxa and groups per sampling site are shown in Table 2. Total mean mesozooplankton abundance (i. e. in the whole water column) was $169.14 \pm 40.35$ ind. $\mathrm{m}^{-3}$ in $\mathrm{CV}$ and $98.47 \pm 13.87$ ind. $\mathrm{m}^{-3}$ in BM, these values ranging between $24.73 \pm 21.60$ and $376.31 \pm 13.29$ ind. $\mathrm{m}^{-3}$ $(\mathrm{CV})$ and $42.36 \pm 22.74$ and $170.97 \pm 91.53$ ind $\mathrm{m}^{-3}(\mathrm{BM})$, respectively.

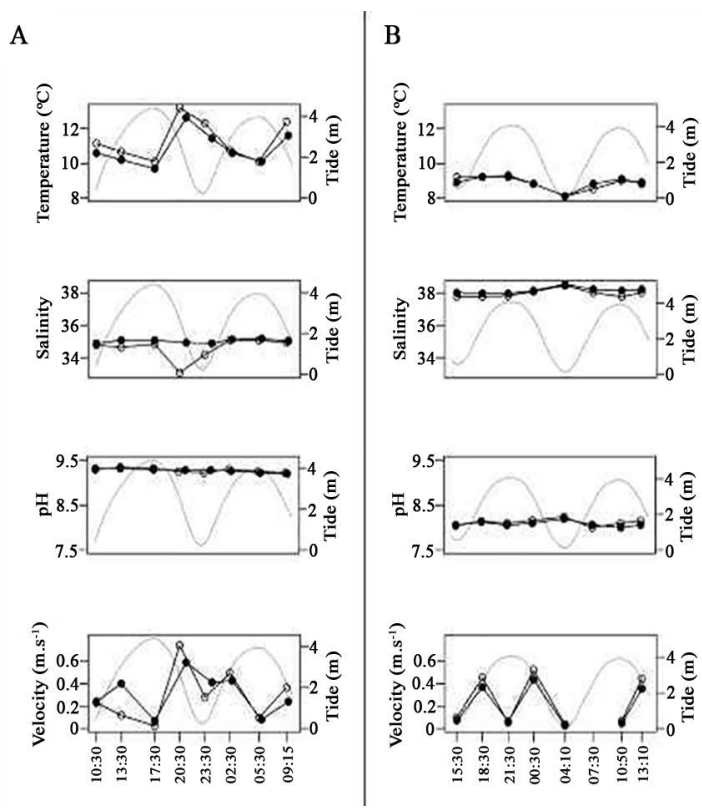

Figure 2. Distribution of temperature, salinity, $\mathrm{pH}$ and water current velocity values across the tidal states of two consecutive tidal cycles during the sampling period (from 07/15/2008 to 07/16/2008 in Canal Vieja and from 07/22/2008 to 07/23/2008 in Bahía del Medio). Solid circles: surface values, outlined circles: bottom values. The tide height shown was measured in Ingeniero White port, located $4.5 \mathrm{~km}$ from Canal Vieja and $5 \mathrm{~km}$ from Bahía del Medio.

The variation in mesozooplancton abundance in the water column at both sampling sites over the two tidal cycles studied is shown in Figure 3. There was a clear difference in the abundance pattern between tidal cycles for both sampling sites. In CV the highest surface mesozooplankton abundance values were observed at the start of the flood condition in the second cycle (363.02 ind. $\left.\mathrm{m}^{-3}\right)$. At the bottom, however, the highest values of mesozooplankton abundance $\left(\geq 200\right.$ ind. $\left.\mathrm{m}^{-3}\right)$ were observed at various tidal states (flood, ebb and start of flood tide) whereas the minimum values were found during low tide and in two-cycle high tides, varying between 3 ind. $\mathrm{m}^{-3}$ and 70 ind. $\mathrm{m}^{-3}$. The abundance pattern of the most abundant taxa along the two tidal cycles (Balanus glandula larvae, Eurytemora americana and Acartia tonsa) in general followed the same trend as that observed for total mesozooplankton. However, unlike the other taxa and total mesozooplankton, surface E. americana did not present a defined peak at the start of the flood tide of the second cycle and $A$. tons $a$ at the bottom did not develop a peak at the same tidal state (Figure 3). In BM the highest surface mesozooplankton abundance values (193.85 ind. $\mathrm{m}^{-3}$ ) were observed at second high tide and a minimum bottom value of 19.62 ind. $\mathrm{m}^{-3}$ at ebb tide. The general pattern over 
Table 1. List of taxa found in mesozooplankton samples from the two channels of Bahía Blanca Estuary (BBE). Taxonomic classification according to MARTIN; DAVIS (2012). L: larvae.

\begin{tabular}{|c|}
\hline Phylum Arthropoda von Siebold, 1848 \\
\hline C. Maxillopoda Dahl, 1956 \\
\hline O. Calanoida Sars, 1903 \\
\hline Acartia tonsa Dana, 1849 \\
\hline Calanoides carinatus (Kroyer, 1849) \\
\hline Eurytemora americana Williams, 1906 \\
\hline Euterpina acutifrons (Dana, 1847) \\
\hline Paracalanus parvus (Claus, 1863) \\
\hline O. Cyclopoida Burmeister, 1835 \\
\hline Halicyclops aff. crassicornis Norman, 1903 \\
\hline Oithona nana Giesbrecht, 1893 \\
\hline O. Harpacticoida (Sars, 1903) \\
\hline Microarthridion littorale (Poppe, 1881) \\
\hline Nannopus aff. palustris Brady, 1880 \\
\hline Stenhelia aff. palustris Boeck, 1865 \\
\hline Tisbe aff. graciloides Lilljeborg, 1853 \\
\hline Tisbe varians Scott T., 1914 \\
\hline O. Pennellidae Burmeister, 1834 \\
\hline Penella sp. Oken, 1815 \\
\hline O. Monstrilloida Sars, 1903 \\
\hline Monstrilla sp. Dana, 1849 \\
\hline O. Sessilia Lamarck, 1818 \\
\hline Balanus glandula Darwin, 1854 L \\
\hline C. Malacostraca Latreille, 1802 \\
\hline O. Amphipoda Latreille, 1816 \\
\hline Monocorophium sp. Bousfield \& Hoover, 1997 \\
\hline O. Decapoda Latreille, 1802 \\
\hline Neohelice granulata (Dana, 1851) L \\
\hline Phylum Echinodermata (Bruguière, 1791) \\
\hline C. Ophiuroidea (Gray, 1840) L \\
\hline Phylum Annelida Lamarck, 1809 \\
\hline C. Polychaeta Grube, 1850 \\
\hline O. Spionida Rouse \& Fauchald, 1997 \\
\hline F. Spionidae Grube, 1850 L \\
\hline
\end{tabular}

the tidal cycles measured at the bottom was the opposite of that observed at the surface. A marked peak was recorded during the last flood tide and a minimum value at the next high tide. At this sampling site, the abundance pattern of the main surface and bottom taxa followed the same general trend as that observed for total mesozooplankton except for E. americana, which did not develop a peak at the second high tide.
According to the Mann-Whitney $U$ test results, total mesozooplankton abundance did not show any significant differences $(p<0.05)$ between depths or between sites (Table 2). The same trend was observed for the abundances of both B. glandula larvae and A. tonsa. However, E. americana presented statistically significant higher abundances in bottom samples from BM than in surface samples, whereas in CV no significant differences between the two depths were found. Adventitious plankton abundance distribution showed the same behavior. Larvae of B. glandula were dominant in surface samples at both sampling sites and in bottom samples from CV, but in BM the most abundant component was the copepod E. americana.

Mean values of taxa richness (S), the Shannon-Wiener diversity index (H'), the evenness (J') and the dominance index $\left(\lambda^{\prime}\right)$ for the two sites and depth strata are shown in Table 3. The Mann-Whitney U test revealed no significant differences between surface and bottom in either of the two channels for any of the indices calculated. Significant differences were found for H', J' and $\lambda^{\prime}$ 'between sites at both surface and bottom.

\section{DISCUSSION}

The highest temperature values in $\mathrm{CV}$, contrasting with those registered in BM, are likely the consequence of two factors, both acting upstream of the sampling point in this channel: i) waste-water effluent from Bahía Blanca city, which is slightly warmer and less saline than the estuarine water; and ii) the discharge of overheated water and effluents from a thermoelectric power plant (HOFFMEYER et al., 2005). CV, unlike BM, is situated on the northern coast of this estuary's main channel and is therefore highly exposed to anthropogenic impacts from human settlements, commercial ports, maritime traffic and petrochemical and chemical industries (MARCOVECCHIO et al., 2008; ARIAS et al., 2010). It also receives most of the direct effect of continental run-off, regional sewage discharge and freshwater flow from the Napostá Grande creek, probably explaining the lower salinity observed there than that in BM. The $\mathrm{pH}$ values found at both sites were consistent with data from other research carried out in the inner zone of the estuary (FREIJE et al., 2008; POPOVICH et al., 2008; DUTTO et al., 2012, SPETTER et al., 2014).

The low taxa richness and abundances found during the present study are a seasonal characteristic of the mesozooplankton of the Bahía Blanca estuary during the winter months (HOFFMEYER, 2004a). The lack of significant 
Table 2. Mean abundance (Standard Error) values of taxa - group. Main taxa and adventitious plankton group ( $>1 \%$ of total abundance) included in the analyses, in decreasing order of abundance. Significant values $(p<0.05$, Mann-Whitney U test) in bold. S, Surface and B, bottom. L: larvae.

\begin{tabular}{|c|c|c|c|c|c|c|c|c|}
\hline \multirow{4}{*}{ Taxa-group } & \multicolumn{3}{|c|}{ Canal Vieja } & \multicolumn{3}{|c|}{ Bahía del Medio } & & \\
\hline & \multirow{3}{*}{$S$} & \multirow{3}{*}{$B$} & \multirow{3}{*}{$\begin{array}{c}\text { Between } \\
\text { depths } \\
P \text {-value }\end{array}$} & \multirow{3}{*}{$S$} & \multirow{3}{*}{$B$} & \multirow{3}{*}{$\begin{array}{c}\text { Between } \\
\text { depths } \\
P \text {-value }\end{array}$} & \multicolumn{2}{|c|}{ Between sites } \\
\hline & & & & & & & $S$ & $\boldsymbol{B}$ \\
\hline & & & & & & & \multicolumn{2}{|c|}{$P$-values } \\
\hline Total Mesozooplankton & $134.88 \pm 43.61$ & $203.63 \pm 51.03$ & 0.200 & $86.5 \pm 19.47$ & $110.45 \pm 24.70$ & 0.299 & 0.300 & 0.172 \\
\hline Balanus glandula $\mathrm{L}$ & $68.82 \pm 28.52$ & $92.90 \pm 27.55$ & 0.264 & $32.77 \pm 9.99$ & $30.18 \pm 8.19$ & 0.377 & 0.247 & 0.057 \\
\hline Eurytemora americana & $35.40 \pm 9.31$ & $64.91 \pm 18.52$ & 0.071 & $18.50 \pm 4.10$ & $32.68 \pm 6.69$ & 0.037 & 0.124 & 0.231 \\
\hline Acartia tonsa & $20.39 \pm 8.26$ & $25.85 \pm 6.11$ & 0.147 & $18.62 \pm 4.59$ & $27.47 \pm 6.37$ & 0.34 & 0.583 & 0.500 \\
\hline Spionidae L & $3.98 \pm 1.26$ & $4.85 \pm 1.42$ & 0.282 & $5.26 \pm 1.77$ & $5.27 \pm 1.00$ & 0.376 & 0.318 & 0.281 \\
\hline Euterpina acutifrons & $2.27 \pm 0.70$ & $5.83 \pm 2.13$ & 0.200 & $8.30 \pm 2.12$ & $9.14 \pm 1.73$ & 0.200 & 0.004 & 0.094 \\
\hline Ophiuroidea L & $2.33 \pm 1.01$ & $5.66 \pm 1.77$ & 0.124 & - & - & - & - & - \\
\hline Neohelice granulata $\mathrm{L}$ & $0.38 \pm 0.20$ & $0.58 \pm 0.23$ & 0.327 & - & - & - & - & - \\
\hline Adventitious plankton & $0.59 \pm 0.23$ & $1.82 \pm 0.80$ & 0.157 & $2.36 \pm 0.43$ & $8.56 \pm 2.84$ & 0.003 & 0.005 & 0.004 \\
\hline
\end{tabular}

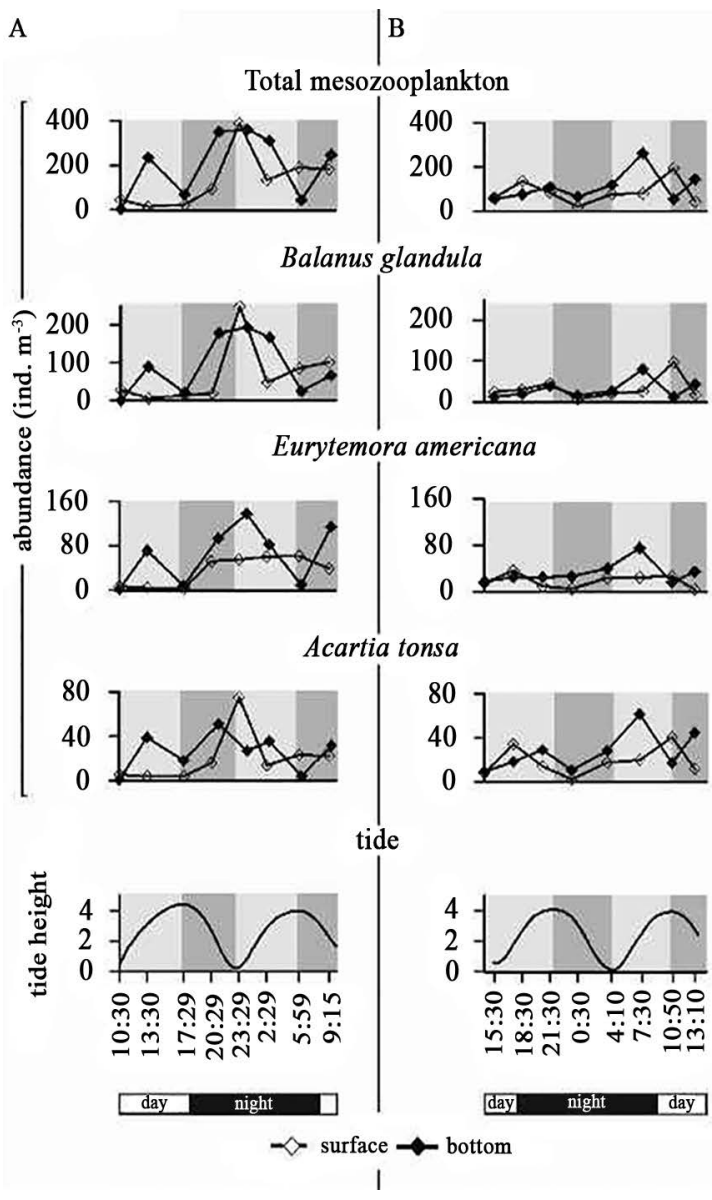

Figure 3. Curves of total mesozooplankton and main taxa - groups in decreasing order of abundance. A) Canal Vieja. B) Bahía del Medio. Solid line: bottom values, dotted line: surface values. Tide height and sampling period details as in Figure 2. Rectangles in black: night, rectangles in white: day. Shaded zones show ebb tide periods and unshaded, flood tide periods. differences in mesozooplankton abundance between the two channels is in agreement with previous studies (DUTTO et al., 2012). However, other attributes such as richness, Shannon diversity, evenness and dominance were found to be significantly different between the channels (Table 3). These findings are contrary to the results obtained by DUTTO et al. (2012), who found no differences in specific composition, diversity and evenness at the same sampling points for the winter of 2009. This discrepancy in findings could be due to the wide inter-anual and inter-date variability of the BBE plankton assemblages and the use of different methodologies - pumps in the present study and surface (0-2 m depth) nets in DUTTO et al. (2012).

Our findings clearly demonstrate the strong effect of the tidal cycle on short-term variations in the mesozooplankton community in both channels of BBE. Similar results have been reported for the main channel of this estuary by MENÉNDEZ et al. $(2011,2012)$ and GARIBOTTI (unpublished data). However, we found, as expected, a different vertical distribution pattern of mesozooplankton during the tidal cycle in the two smaller channels from that of the main channel. Studies on several different estuaries around the world have also demonstrated the effect of semidiurnal tidal cycles on zooplankton community distribution and transport (TRINAST, 1975; LEE; Mc ALICE, 1979; DAUVIN et al., 1998; KIMMERER et al., 2002; KRUMME; LIANG, 2004; HSIEH et al., 2010). In our study, temporal and vertical spatial mesozooplankton distribution varied between tidal states in both channels, presenting a distinct pattern in each channel. At CV, mesozooplankton abundance in the water column reached its highest values at the start of the 
Table 3. Mean (SE) values calculated for richness (number of taxa - S), diversity (Shannon-Wiener index - H'), eveness $\left(J^{\prime}\right)$ and Simpson's dominance index ( $\lambda$ '). Significant values $(p<0.05$, Mann-Whitney U test) in bold. Meaning of S and $\mathrm{B}$ as in Table 2 .

\begin{tabular}{|c|c|c|c|c|c|c|c|c|}
\hline \multirow{4}{*}{$\begin{array}{l}\text { Diversity para- } \\
\text { meters }\end{array}$} & \multicolumn{2}{|c|}{ Canal Vieja } & \multicolumn{4}{|c|}{ Bahía del Medio } & & \\
\hline & \multirow{3}{*}{$S$} & \multirow{3}{*}{$\boldsymbol{B}$} & \multirow{3}{*}{$\begin{array}{c}\text { Between } \\
\text { depths } \\
P \text {-value }\end{array}$} & \multirow{3}{*}{$S$} & \multirow{3}{*}{$\boldsymbol{B}$} & \multirow{3}{*}{$\begin{array}{c}\text { Between } \\
\text { depths } \\
P \text {-value }\end{array}$} & \multicolumn{2}{|c|}{ Between sites } \\
\hline & & & & & & & $S$ & $B$ \\
\hline & & & & & & & \multicolumn{2}{|c|}{$P$-values } \\
\hline Richness (S) & $9.00 \pm 0.78$ & $9.75 \pm 1.01$ & 0.170 & $8.88 \pm 0.48$ & $9.50 \pm 0.38$ & 0.152 & 0.500 & 0.143 \\
\hline Diversity (H') & $0.56 \pm 0.02$ & $0.58 \pm 0.04$ & 0.542 & $0.66 \pm 0.02$ & $0.69 \pm 0.01$ & 0.147 & 0.001 & 0.006 \\
\hline Evenness ( $\left.\mathrm{J}^{\prime}\right)$ & $0.60+0.03$ & $0.61 \pm 0.04$ & 0.396 & $0.71 \pm 0.03$ & $0.71 \pm 0.01$ & 0.337 & 0.015 & 0.029 \\
\hline Dominance $\left(\lambda^{\prime}\right)$ & $0.35 \pm 0.06$ & $0.30 \pm 0.10$ & 0.172 & $0.25 \pm 0.02$ & $0.24 \pm 0.01$ & 0.172 & 0.004 & 0.006 \\
\hline
\end{tabular}

flood tide and its lowest at high tide (Figure 3), which could be partly due to the decrease and increase in water volume, respectively (tidal range reaches $3.3 \mathrm{~m}$ ). Regarding the relationship between the copepod Acartia tonsa, the key native copepod species in the BBE, and the tidal cycle, our results from $\mathrm{CV}$ are in good agreement with those of LEE; Mc ALICE (1979), who observed the highest abundances of this species in the Damariscotta River estuary near low water tide. At BM, mesozooplankton abundance in the water column also reached its highest values at flood tide (Figure 3). The difference between the two channels in terms of the distribution patterns of mesozooplankton abundance over the tidal cycles could thus be attributed to their different geomorphology and dynamics and their specific location in the estuary. CV connects directly to the main channel and lies parallel to this to the north; BM on the other hand is a secondary meandering channel within a looping-channel system and connects in the south with the main navigation channel by an intermediate channel (CUADRADO, unpublished data; HOFFMEYER; BARRIA, 2007), the latter also having a tidal range of above $4 \mathrm{~m}$.

Mesozooplankton abundance, and particularly those of the species studied, was greater near the channel bottom during most of the tidal cycles with the exception of the second high tide, when it was lower near the channel bottom at both sites (Figure 3 ). This latter vertical abundance pattern was not observed at low tide, possibly because of the shallowness of the channel, and was not observed during the high tide of the first tidal cycle possibly because, during the first high tide, the velocity at the surface was slightly lower than at the bottom, but in the second high tide the opposite occurred (Figure 2). At ebb tide, with fast currents, higher abundance values were observed near the bottom in both channels. This pattern was especially clear for the copepods A. tonsa and E. americana, and also for the nauplius larvae of the cirriped $B$. glandula. The latter pattern is consistent in part with that reported by MENENDEZ et al. $(2011,2012)$ for the main channel in the inner zone of the BBE since those authors found the highest abundances at the bottom throughout the tidal cycle. Other authors have also found a higher abundance of $A$. tonsa at depth during the ebb tide in estuaries (TRINAST, 1975; GONÇALVES et al., 2012). This fact has been also reported for E. americana by Bakker et al. (1977). In a study of the Mondego River estuary on the west coast of Portugal, MARQUES et al. (2009) also found high densities of $A$. tonsa mostly in bottom waters. Their findings suggest that this copepod might use a retention mechanism to maintain its position in the channel, combining swimming behavior that allows regulation of vertical distribution synchronouly with the tidal cycle (KOUASSI et al., 2001; Marques et al., 2009). Tidal vertical migration (TVM), a tide-dependent mechanism whereby some zooplanktonic species are able to maintain their position in estuaries, has been reported in several studies on copepods (KIMMERER; MCKINNON, 1987; HOUGH; NAYLOR, 1991; MORGAN et al., 1997; SHANG et al., 2007; UEDA et al., 2010), crab larvae (CRONIN; FORWARD, 1979), mysids and amphipods (KIMMERER et al., 1998). The retention efficiency of TVM depends on the swimming ability of the zooplankton. This mechanism is hypothesized as responsible for zooplankton's ability to concentrate in the deeper layers of the water column at ebb tide and in the upper layers at flood tide (UEDA et al., 2010). In other words, it serves to limit population loss through net seaward flow since seaward flow during ebb tides and landward flow during flood tides are for the most part faster in the upper layers of the water column. Within this context, we suggest that organisms in the BBE might use the mechanism of TVM during the second tidal cycle, since they remain near the bottom during the ebb tide, avoiding faster currents, and subsequently become resuspended in 
the flood tide, staying actively near the surface at high tide close to slack times. This active maintenance of mesozooplankton in the upper stratum of the water column also reflects the positive phototaxis behavior of $B$. glandula larvae, the most abundant taxa in the samples. Similar behavior has been documented for other cirriped species such as Amphybalanus amphitrite (CHIANG et al., 2007) which also inhabits this estuary and reaches greater abundance during warmer months.

In conclusion, a discernible variability in the water conditions as well as in the vertical distribution of mesozooplankton was found in both the small channels studied in the Bahía Blanca estuary, linked to the tidal cycle and the channel's geomorphology and dynamics. When our findings were compared with those obtained for the BBE's main channel, differences in the mesozoopalnkton vertical distribution patterns emerged. Further studies are required in order to shed more light on the relevant relationships between water circulation and distribution of plankton in these smaller channels.

\section{ACKNOWLEDGEMENTS}

We wish to thank Luis Kaufman and the IADO boat staff: Camilo Bernárdez, Enio Redondo and Alberto Conte, for their technical support and help during sampling. We would also thank Ernesto Alberdi for performing the current measurements and Dr. Walter Melo for drawing the map. General suggestions made during the study by Dr. M. Sofía Dutto, Lic. M. Celeste López Abbate, Lic. Cecilia Carcedo were also much appreciated. The study was supported by a grant from the Agencia Nacional de Promoción Científica y Tecnológica to M.S.H (FONCYT, PICT 20061713) and the Instituto Argentino de Oceanografía, IADO (CONICET-UNS).

\section{REFERENCES}

ARIAS, A. H.; VAZQUEZ-BOTELLO, A.; TOMBESI, N.; PONCE-VÉLEZ, G.; FREIJE, H.; MARCOVECCHIO, J. Presence, distribution, and origins of polycyclic aromatic hydrocarbons (PAHs) in sediments from Bahía Blanca estuary, Argentina. Environ. Monit. Assess., v. 160, n. 1-4, p. 301-314, 2010.

BAKKER, C.; PHAFF, W. J.; EWIJK-ROSIER, M. V.; DE PAUW, $\mathrm{N}$. Copepod biomass in an estuarine and a stagnant brackish environment of the SW Netherlands. Hydrobiologia, v. 52, n. 1, p. 3-13, 1977.

BALDINI, M. D.; CUBITTO, M. A.; CHIARELlO, M. N.; CABEZALÍ, C. B. Water quality for aquaculture development in Bahia Blanca estuary, Argentina. Bacteriological studies. Rev. Argent. Microbiol., v. 31, n.1, p. 19-24, 1999.
BIANCALANA, F.; MENÉNDEZ, M. C.; BERASATEGUI, A. A.; FERNÁNDEZ-SEVERINI, M. D.; HOFFMEYER, M. S. Sewage pollution effects on mesozooplankton structure in a shallow temperate estuary. Environ. Monit. Assess., v. 184, n. 6, p. 39013913, 2012.

BOLTOVSKOY, D. (Ed.). South Atlantic Zooplankton. Leiden. Backhuys Publishers, 1999.

CLARKE, K. R.; GORLEY, R. N. User manual/tutorial. Plymouth: PRIMER-E, 2006.

CHIANG, W. L.; WU, R. S. S.; YU, P. K. N.; AU, D. W. T. Are barnacle larvae able to escape from the threat of UV? Mar. Biol., v. 151, n. 2, p. 703-711, 2007.

CRONIN, T. W., AND R. B. FORWARD, JR. 1979. Tidal vertical migration: an endogenous rhythm in estuarine crab larvae. Science 205: 1020-1022.

CUADRADO, D. G.; GINSBERG, S. S.; GÓMEZ, E. A. Geomorfología. In: PICCOLO, M. C.; HOFFMEYER M. S. (Eds.). El Ecosistema del Estuario de Bahía Blanca. Bahía Blanca: Instituto Argentino de Oceanografía, 2000. p. 29-38.

DA COSTA, K. G.; BEZERRA, T. R.; MONTEIRO, M. C.; VALLINOTO, M.; BERRÊDO, J. F.; PEREIRA, L. C. C.; DA COSTA, R. M. Tidal-induced changes in the zooplankton community of an Amazon estuary. J. Coastal. Res., v. 29, n. 4, p. 756-765, 2013.

DAUVIN, J. C.; THIÉBAUT, E.; WANG, Z. Short-term changes in the mesozooplanktonic community in the Seine ROFI (Region of Freshwater Influence) (eastern English Channel). J. Plankton. Res., v. 20, n. 6, p. 1145-1167, 1998.

DEVREKER, D.; SOUISSI, S.; MOLINERO, J. C.; BEYREND-DUR, D.; GOMEZ, F.; FORGET-LERAY, J. Tidal and annual variability of the population structure of Eurytemora affinis in the middle part of the Seine Estuary during 2005. Estuar. Coast. Shelf. Sci., v. 89, n. 4, p. 245-255, 2010.

DEVREKER, D.; SOUISSI, S.; MOLINERO, J. C.; NKUBITO, F. Trade-offs of the copepod Eurytemora affinis in mega-tidal estuaries: insights from high frequency sampling in the Seine estuary. J. Plankton. Res., v. 30, n. 12, p. 1329-1342, 2008.

DUTTO, M. S.; ABBATE, M. C.; BIANCALANA, F.; BERASATEGUI, A. A.; HOFFMEYER, M. S. The impact of sewage on environmental quality and the mesozooplankton community in a highly eutrophic estuary in Argentina. ICES J. Mar. Sci., v. 69, n. 3, p. 399-409, 2012.

FREIJE, R. H.; SPETTER, C. V.; MARCOVECCHIO, J. E.; POPOVICH, C. A.; BOTTÉ, S. E.; NEGRÍN, V.; ARIAS, A. Water chemistry and nutrients in the Bahía Blanca Estuary. In: NEVES. R.; BARETTA, J.; MATEUS, M. (Eds.). Perspectives on integrated coastal zone management in South America. Portugal: IST Press, 2008. p. 241-254.

GARRISON, L. P. Vertical migration behavior and larval transport in brachyuran crabs. Mar. Ecol. Prog. Ser., v. 176, p. 103-113, 1999.

GINSBERG, S. S.; ALIOTTA, S. Sediment Transport Circulation Pattern through Mesotidal Channels System. In: GINSBERG, S. S. (Ed.). Sediment Transport. Croatia: InTech, 2011. p. 275294.

GONÇALVES, A. M. M.; PARDAL, M. A.; MARQUES, S. C.; MENDES, S.; FERNÁNDEZ-GÓMEZ, M. J.; GALINDO-VILLARDÓN, M. P.; AZEITEIRO, U. M. Diel vertical behavior of Copepoda community (naupliar, copepodites and adults) at the boundary of a temperate estuary and coastal waters. Estuar. Coast. Shelf. Sci., v. 98, p. 16-30, 2012. 
HILL, A. E. Vertical migration in tidal currents. Mar. Ecol. Prog. Ser., v. 75, n. 1, p. 39-54, 1991.

HOFFMEYER, M. S. Zooplancton del área interna de la Bahía Blanca (Buenos Aires, Argentina), I- Composición faunística. Hist. Nat., v. 3, n. 8, p. 73-94, 1983.

HOFFMEYER, M. S. Decadal change in zooplankton seasonal succession in the Bahía Blanca estuary, Argentina, following introduction of two zooplankton species. J. Plankton. Res., v. 26, n. 2, p. 181-189, 2004.

HOFFMEYER, M. S. Mesozooplancton. In: PICCOLO, M. C.; HOFFMEYER M. S. (Eds.). El Ecosistema del Estuario de Bahía Blanca. Bahía Blanca: Publicación Especial Instituto Argentino de Oceanografía (CONICET-UNS), 2004. p. 133-141.

HOFFMEYER, M. S.; BARRÍA DE CAO, M. S. Zooplankton assemblages from a tidal channel in the Bahía Blanca Estuary, Argentina. Braz. J. Oceanogr., v. 55, n. 2, p. 97-107, 2007.

HOFFMEYER, M. S.; BIANCALANA, F.; BERASATEGUI, A. A. Impact of a power plant cooling system on copepod and meroplankton survival (Bahía Blanca estuary, Argentina). Iheringia Ser. Zool., v. 95, n. 3, p. 311-318, 2005.

HOFFMEYER, M. S.; CERVELLINI, P. M. Zooplancton Temporario. In: PICCOLO, M. C.; HOFFMEYER M. S. (Eds.). El Ecosistema del Estuario de Bahía Blanca. Bahía Blanca: Editorial de la Universidad Nacional del Sur, 2004. p. 153-161.

HOFFMEYER, M. S.; MIANZAN, H. W. Macro-zooplancton del estuario y aguas costeras adyacentes. In: PICCOLO, M. C.; HOFFMEYER M. S. (Eds.). El Ecosistema del Estuario de Bahía Blanca. Bahía Blanca: Editorial de la Universidad Nacional del Sur, 2004. p. 143-151.

HOUGH, A. R.; NAYLOR, E. Field studies on retention of the planktonic copepod Eurytemora affinis in a mixed estuary. Mar. Ecol. Prog. Ser., v. 76, p. 115-122, 1991.

HSIEH, H. L.; FAN, L. F.; CHEN, C. P.; WU, J. T.; LIU, W. C. Effects of semidiurnal tidal circulation on the distribution of holo-and meroplankton in a subtropical estuary. J. Plankton. Res., v. 32, n. 6, p. 829-841, 2010.

JAGER, Z. Selective tidal stream transport of flounder larvae (Platichthys flesus L) in the Dollard (Ems Estuary). Estuar. Coast. Shelf. Sci., v. 49, n. 3, p. 347-362, 1999.

JAGGER, Z. Selective stream transport of the flounder larvae (Platichthys flesus L.) in the Dolard (Ems Estuary). J. mar. Bio. Ass. U.K, v. 75, p. 3-13, 1999.

KIMMERER, W. J.; BURAU, J. R.; BENNETT, W. A. Tidally oriented vertical migration and position maintenance of zooplankton in a temperate estuary. Limnol. Oceanogr., v. 43, n. 7, p. 1697-1709, 1998.

KIMMERER, W. J.; BURAU, J. R.; BENNETT, W. A. Persistence of tidally-oriented vertical migration by zooplankton in a temperate estuary. Estuaries, v. 25, n. 3, p. 359-371, 2002.

KOUASSI, E.; PAGANO, M.; SAINT-JEAN, L.; ARFI, R.; BOUVY, M. Vertical Migrations and Feeding Rhythms of Acartia clausi and Pseudodiaptomus hessei (Copepoda: Calanoida) in a Tropical Lagoon (Ebrié, Côte d'Ivoire). Estuar. Coast. Shelf Sci., v. 52, n. 6, p. 715-728, 2001.

KRUMME, U.; LIANG, T. H. Tidal induced changes in a copepod-dominated zooplankton community in a macrotidal mangrove channel in Northern Brazil. Zool. Stud., v. 43, n. 2, p. 404-414, 2004.
LEANDRO, S. M.; MORGADO, F.; PEREIRA, F.; QUEIROGA, $\mathrm{H}$. Temporal changes of abundance, biomass and production of copepod community in a shallow temperate estuary (Ria de Aveiro, Portugal). Estuar. Coast. Shelf Sci., v. 74, n. 1-2, p. 215-222, 2007.

LEE, W. Y.; Mc ALICE, B. J. Sampling variability of marine zooplankton in a tidal estuary. Estuar. Coast. Mar. Sci., v. 8, n. 6, p. 565-582, 1979.

MARCOVECCHIO, J. E.; BOTTÉ, S. E.; ARIAS, A. H.; FERNÁNDEZ SEVERINI, M. D.; DE MARCO, S.; TOMBESI, N.; FREIJE, H. Pollution Processes in Bahía Blanca estuarine environment. In: NEVES. R.; BARETTA, J.; MATEUS, M. (Eds.). Perspectives on integrated coastal zone management in South America. Portugal: IST Press, 2008. p. 303-316.

MARQUES, S. C.; AZEITEIRO, U. M.; MARTINHO, F.; VIEGAS, I.; PARDAL, M. A. Evaluation of estuarine mesozooplankton dynamics at a fine temporal scale: the role of seasonal, lunar and diel cycles. J. Plankton. Res., v. 31, n. 10, p. 1249-1263, 2009.

MARTIN, J. W.; DAVIS, G. E. An updated classification of the recent Crustacea. Los Angeles: Natural History Museum of Los Angeles County, 2001. 132 p.

MENÉNDEZ, M. C.; PICCOLO, M. C.; HOFFMEYER, M. S. Short-term variability on mesozooplankton community in a shallow mixed estuary (Bahía Blanca, Argentina): Influence of tidal cycles and local winds. Est. Coast. Shelf Sci., v. 112, p. 11-22, 2012.

MENÉNDEZ, M. C.; PICCOLO, M. C.; HOFFMEYER, M. S.; SASSI, M. Estuarine mesozooplankton dynamics on a short-term time scale: role of semidiurnal tidal cycle. Braz. J. Oceanogr., v. 59, n. 3, p. 281-286, 2011.

MORGADO, F. M.; PASTORINHO, R.; QUINTANEIRO, C.; RÉ, $\mathrm{P}$. Vertical distribution and trophic structure of the macrozooplankton in a shallow temperate estuary (Ria de Aveiro, Portugal). Sci. Mar., v. 70, n. 2, p. 177-188, 2006.

MORGAN, C. A.; CORDELL, J. R.; SIMENSTAD, C. A. Sink or swim? Copepod population maintenance in the Columbia River estuarine turbidity-maxima region. Mar. Biol., v. 129, n. 2, p. 309-317, 1997.

Mouny P, Dauvin J-C (2002) Environmental control of mesozooplankton community in the Seine estuary (English Channel). Oceanol Acta 25:13-22.

NAYLOR, E. Orientation and navigation in coastal and estuarine zooplankton. Mar. Freshw Behav. Physiol., v. 39, n. 1, p. 1324, 2006.

PEITSCH, A.; KÖPCKE, B.; BERNÁT, N. Long-term investigation of the distribution of Eurytemora affinis (Calanoida; Copepoda) in the Elbe Estuary. Limnologica, v. 30, n. 2, p. 175-182, 2000.

PEREIRA, F.; PEREIRA, R.; QUEIROGA, H. Flux of decapod larvae and juveniles at a station in the lower Canal de Mira (Ria de Aveiro, Portugal) during one lunar month. Invertebr. Reprod. Dev., v. 38, n. 3, p. 183-206; 2000.

PERILlO, G. M.; PICCOLO, M. C.; PARODI, E.; FREIJE, R. H. The Bahía Blanca Estuary, Argentina. In: SEELIGER U; KJERFVE B. (Ed.). Coastal marine ecosystems of Latin America. Berlin: Springer, 2001. p. 205-217.

PERILlO, G. M.; PICCOLO, M. C. Tidal response in the Bahía Blanca estuary, Argentina. J. Coastal. Res., p. 437-449, 1991.

PIELOU, E. C. Ecological diversity. New York: Wiley, 1975. 173 p. 
POPOVICH, C. A.; SPETTER, C. V.; MARCOVECCHIO, J. E.; FREIJE, R. H. Dissolved nutrient availability during winter diatom bloom in a turbid and shallow estuary (Bahía Blanca, Argentina). J. Coastal. Res., v. 24, n. 1, p. 95-102, 2008.

ROMAN, M. R.; HOLLIDAY, D. V.; SANFORD, L. P. Temporal and spatial patterns of zooplankton in the Chesapeake Bay turbidity maximum. Mar. Ecol. Prog. Ser., v. 213, p. 215-227, 2001.

Schmidt, G.A., J.H. Jungclaus, C.M. Ammann, E. Bard, P. Braconnot, T.J. Crowley, G. Delaygue, F. Joos, N.A. Krivova, R. Muscheler, B.L. Otto-Bliesner, J. Pongratz, D.T. Shindell, S.K. Solanki, F. Steinhilber, and L.E.A. Vieira, 2011: Climate forcing reconstructions for use in PMIP simulations of the last millennium (v1.0). Geosci. Model Dev., 4, 33-45.

SCHWAMBORN, R.; MELO Jr, M.; DE LEITÃO, S. L.; EKAU, W.; PARANAGUÁ, M. N. Dynamic patterns of zooplankton transport and migration in Catuama Inlet (Pernambuco, Brazil), with emphasis on the decapod crustacean larvae. Lat. Am. J. Aquat. Res., v. 36, n. 1, p. 109-113, 2008.

SHANG, X.; GUIZHONG, W.; SHAOJING, L.; DONGHUI, G. Preliminary study of the retention mechanism of planktonic copepods in the Jiulong Estuary in China. Acta. Oceanol. Sin., v. 26, p. 156-163, 2007.

SHANNON, C. E.; WEAVER, W. The mathematical theory of communication. Urbana: University of Illinois Press, 1949. 125 p.

SIMPSON, E. H. Measurement of diversity. Nature, v. 163, p. 688$688,1949$.

SPETTER, C. V.; POPOVICH, C. A.; ARIAS, A.; ASTEASUAIN, R. O.; FREIJE, R. H.; MARCOVECCHIO, J. E. Role of Nutrients in Phytoplankton Development during a Winter Diatom Bloom in a Eutrophic South American Estuary (Bahía Blanca, Argentina). J. Coastal. Res., v. 31, n. 1, p. 76-87, 2015.

THORISSON, K. How are the vertical migrations of copepods controlled? J. Exp. Mar. Biol. Ecol., v. 329, n. 1, p. 86-100, 2006.
TOMBESI, N. B.; PISTONESI, M. F.; FREIJE, R. H. Physico-chemical characterization and quality improvement evaluation of primary treated municipal waste water in the City of Bahía Blanca (Argentina). Ecol. Environ. Conserv., v. 6, n. 2, p. $147-151,2000$.

TRINAST, E. M. Tidal currents and Acartia distribution in Newport Bay, California. Estuar. Coast. Mar. Sci., v. 3, n. 2, p. 165-176, 1975.

UEDA, H.; KUWATANI, M.; SUZUKI, K. W. Tidal vertical migration of two estuarine copepods: naupliar migration and position-dependent migration. J. Plankton. Res., v. 32, n. 11, p. 1557-1572, 2010.

VILLATE, F. Tidal influence on zonation and occurrence of resident and temporary zooplankton in a shallow system (estuary of Mundaka, Bay of Biscay). Sci. Mar., v. 61, n. 2, p. 173-188, 1997.

W. J. Kimmerer and A. D. McKinnon, 1987. Growth, mortality, and secondary production of the copepod Acartia tranteri in Westernport Bay. Limnol. Oceanogr., 32(1): 14-28

WIAFE G. \& FRID C. L. J. 1996. Short-term temporal variation in coastal zooplanktoncommunities: the relative importance of physical and biological mechanisms. Journal of Plankton Research, 8(8): 1485-1501

WILSON, J. G. Productivity, fisheries and aquaculture in temperate estuaries. Estuar. Coast. Shelf. Sci., v. 55, n. 6, p. 953967, 2002.

WOOLDRIDGE, T.; ERASMUS, T. Utilization of tidal currents by estuarine zooplankton. Estuar. Coast. Mar. Sci., v. 11, n. 1, p. $107-114,1980$.

YOUNG, C. M. Atlas of marine invertebrate larvae, 2th ed. London: Academic press, 2002. $626 \mathrm{p}$

ZAR, J. H. Biostatistical Analysis, 4th ed. Upper Saddle River: Prentice Hall, 1999. 663 p. 